\title{
環境水中のジエチルスチルベストロールの高感度分析法
}

\author{
長谷川 瞳1), 渡辺 正敏2), 鈴木 茂3) \\ 1)名古屋市環境科学調查センター（テ457-0841 愛知県名古屋市南区豊田5-16-8） \\ 2)前名古屋市環境科学調査センター（４57-0841 愛知県名古屋市南区豊田5-16-8) \\ ${ }^{3)}$ 中部大学大学院応用生物学研究科（广487-8501 愛知県春日井市松本町 1200）
}

[平成24年 6 月18日受付，平成24年12月25日受理］

\section{An Analytical Method for the Determination of Trace Levels of Diethylstilbestrol in Environmental Water}

\author{
Hitomi HASEGAWA ${ }^{1)}$, Masatoshi WATANABE ${ }^{2)}$ and Shigeru SUZUKI ${ }^{3)}$ \\ ${ }^{1)}$ Nagoya City Environmental Science Research Institute \\ (5-16-8 Toyoda, Minami, Nagoya, Aichi 457-0841) \\ ${ }^{2)}$ Pre-Nagoya City Environmental Science Research Institute \\ (5-16-8 Toyoda, Minami, Nagoya, Aichi 457-0841) \\ ${ }^{3)}$ Graduate School of Bioscience and Biotechnology, Chubu University \\ (1200 Matsumoto, Kasugai, Aichi 487-8501)
}

[Received June 18, 2012; Accepted December 25, 2012]

\begin{abstract}
Summary
A liquid chromatography tandem-mass spectrometry (LC/MS/MS) method has been developed for highly sensitive determination of diethylstilbestrol (DES) in water.

Two grams of ascorbic acid and five nano grams of diethylstilbestrol- $d 8$ as the surrogate were added to every 2000 $\mathrm{mL}$ of water sample. The sample was filtrated with glass fiber filter (GS25) and adjusted to $\mathrm{pH} 2.5$ with $6 \mathrm{~mol} / \mathrm{L}$ of $\mathrm{HCl}$ followed by solid phase extraction with a cyclohexyl silica cartridge (InertSep CH). The fraction eluted with $5 \mathrm{~mL}$ of methanol was passed through a multilayer solid phase extraction cartridge (GC/SAX/PSA) to remove matrices. The analyte was eluted from the cartridge with $12 \mathrm{~mL}$ of methanol. The elute was concentrated to volume approximately $0.25 \mathrm{~mL}$ in a test tube at $40{ }^{\circ} \mathrm{C}$ in water bath under nitrogen gentle stream, and then it was filled up to $0.5 \mathrm{~mL}$ with pure water for LC/MS/MS measurement.

Negative electrospray ionization (ESI-negative) was used to ionize diethylstilbestrol and the internal standard (i.e. diethylstilbestrol- $d 8$ ). The determination was performed by the selected-reaction-monitoring (SRM) method using precursor/product ion transition m/z 267. 45 to 237.41 for diethylstilbestrol and m/z 275. 43 to 245.47 for diethylstilbestrol$d 8$.

The method detection limit (MDL) and the method quantification limit (MQL) are $0.005 \mathrm{ng} / \mathrm{L}$ and $0.013 \mathrm{ng} / \mathrm{L}$, respectively. The average recoveries $(n=5)$ from river water and sea water spiked with $0.5 \mathrm{ng}$ of diethylstilbestrol are $104 \%$ (RSD 4. $0 \%$ ) and 106\% (RSD 2. 9\%), respectively.

In all the river waters and sea waters sampled in Nagoya city, the concentrations of diethylstilbestrol were below the MDL.
\end{abstract}

Key words: diethylstilbestrol, LC/MS/MS, multilayer solid phase extractiona

\section{1. はじめに}

ジエチルスチルベストロール（Diethylstilbestrol, DES）は，か つて流産防止剂などに用いられてきた合成女性ホルモンの薬剂で, IARC 発ガン性リスクの Group 1 に分類されている。1938 年にイギ リスで合成され, 女性ホルモン様作用が発見されて以降, 切迫流産 防止剂としてだけでなく，更年期障害・老人性臄炎・不妊症に対し
ても広く用いられてきた11。アメリカに拈いては, 1938 年から 1971 年にかけて 500 ～ 1000 万人に処方されたとも言われている。1970 年代以降, 胎児期にDES の暴露を受けた女性に臸腺ガンや子宮形 成不全などの女性器障害が発生 ${ }^{2}$, 同男性についても生殖器異常の 確率が高(3) との報告があり，DES 使用によるヒトへの影響が懸 念されるようになった ${ }^{4-6)}$ 。その後, アメリカ食品医薬品局（FDA） は 1971 年に妊婦に対するDES の使用を禁止し, 厚生省（現厚生労 
働省）は同年 12 月，薬務局長名で，DESまたはその誘導体を含む 製剂（外用剂除く）は，「妊娠中は使用しないこと，また，効能の 事項に『流産，習慣性流産』など妊娠に使用されるおそれのある表 示があれば削除するように」という通知を出した。

DESのように女性ホルモン様作用を持つステロイドホルモン類 は，極微量であっても生物に影響を与える可能性が高いとされる ため7), 環境中における微量の DESの高感度分析が求められる。 日本においては，DESの環境基準值は設定されていないが，厚生 労働省が定める残留農薬等ポジティブリスト制度では, 食品中の DES は不検出であること，と設定されており，その検出下限值は $0.0005 \mathrm{ppm}(500 \mathrm{ng} / \mathrm{L})$ と定められている。また、環境省は、既 報の毒性情報に基づいて ${ }^{8}$ ，環境水中の DES をより高感度で測定 すべきとの方針を出し、検出下限值を $0.01 \mathrm{ng} / \mathrm{L}$ と設定している。

これまで, $\mathrm{GC} / \mathrm{MS}$ や LC/MSにより，環境中における種々のス テロイドホルモン類の測定がなされ， $\mathrm{ng} / \mathrm{L} \sim \mu \mathrm{g} / \mathrm{L} レ$ ベルでの検 出が報告されている ${ }^{9,10)}$ 。DES については，環境水や下水処理水か ら, 溶媒抽出法や $\mathrm{C} 18$ などによる固相抽出法 ${ }^{11,12)} に よ り$, 検出下 限值数〜数百 $\mathrm{ng} / \mathrm{L}$ レベルの報告がなされている ${ }^{11-15)}$ が、環境省の 方針に対応する検出下限值を満足するには，試料濃縮率や精製方法 の改良が求められる。

著者等は, 試料のクリーンアップ方法，大量試料導入方法を検 討し，環境水中の DES の高感度分析方法（検出下限值 $0.01 \mathrm{ng} / \mathrm{L}$ ) を開発し，環境を調査した。ここでは，開発した分析方法の要素技 術の検討結果および，名古屋市内で行った環境調査結果について報 告する。

\section{2. 実験}

\section{1 試薬}

DES (純度 $98+\%$, HPLC 用), アセトン (残留農薬試験用), ヘ キサン (残留農薬試験用), $1 \mathrm{~mol} / \mathrm{L}$ 酢酸アンモニウム溶液 $(\mathrm{LC} / \mathrm{MS}$ 用）は和光純薬(株)（大阪）製，DES- $d_{8}$ （純度 $98.7 \%$ ）は CDN isotopes 社製 (Quebec, Canada)を使用した。メタノール (LC/MS 用) は関東化学(株)（東京）製を使用した。

DES 標準原液, 標準液は, DESをメタノールで希釈して作製し た。DES- $d_{8}$ も同様にしてメタノールで希釈して内標準液を作製し た。内標準液は，各検量線用標準液および試験液中に $10.0 \mathrm{ng} / \mathrm{mL}$ になるように添加した。

\section{2 器具および装置}

水質試料からの抽出には，シクロヘキシルシリカカートリッジ (InertSep CH 500 mg, GL Sciences 社, 東京), 試験液のクリーンアッ プにはグラファイトカーボン／強陰イオン交換/極性相互作用＋陰 イオン交換混合固相 (InertSep GC/SAX/PSA $500 \mathrm{mg} / 500 \mathrm{mg} / 500$ $\mathrm{mg}$, GL Sciences 社, 東京) を使用し, 固相への通液はコンセント レーター(Waters 社, Milford, MA, USA) により行った。濃縮操作 は窒素吹付装置を用いて行った。

LC-MS 測 定 は Alliance2695/Micromass Quattro micro API （Waters 社, Milford, MA, USA）を用い, 定量は ESI-Negative-SRM モードにより行った。測定条件を以下に示す。

〔LC 条件

\section{LC : Alliance 2695}

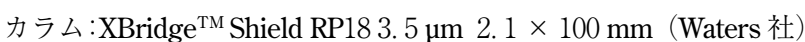
移動相：A：2 m mol/L酶酸アンモニウム水溶液 $\mathrm{B}:$ メタノール $0 \sim 5 \mathrm{~min} \quad \mathrm{~A}: 70 \rightarrow 20 \quad \mathrm{~B}: 30 \rightarrow 80$ linear gradient $5 \sim 20 \mathrm{~min} \quad \mathrm{~A}: 20$ B : 80
$20 \sim 22 \min$
A : $20 \rightarrow 70$
B : $80 \rightarrow 30$ linear gradient
$22 \sim 30 \mathrm{~min}$
A : 70
B : 30

流量 : $0.2 \mathrm{~mL} / \mathrm{min}$

カラム温度 : $40{ }^{\circ} \mathrm{C}$, 注入量 : $100 \mu \mathrm{L}$

[MS 条件]

MS: Micromass Quattro micro API

Cone voltage : $40 \mathrm{~V}, \quad$ Collision Energy: $30 \mathrm{eV}$

Capillary voltage: $3 \mathrm{kV}$, Source Temp.: $120^{\circ} \mathrm{C}$,

Desolvation

Temp.: $350{ }^{\circ} \mathrm{C}$

Desolvation Gas: 700 L/hr, Cone Gas: 50 L/hr

イオン化法：ESI-Negative-SRM

モニターイオン $:$ DES $267.45 \rightarrow 237.41$, DES- $d_{8} 275.43 \rightarrow 245.47$

\section{3 分析方法}

水試料 $2 \mathrm{~L} に, D E S$ のエノール性 $\mathrm{OH}$ 基の酸化分解を抑える ことを目的としてアスコルビン酸 $2 \mathrm{~g}$ を添加し，さらにサロゲート として DES- $d 8$ 溶液 $(1 \mu \mathrm{g} / \mathrm{mL})$ を $5 \mu \mathrm{L}$ 添加後, 万過した。ろ紙上 の SS はメタノール $5 \mathrm{~mL}$ で 2 回洗い込み，万液と合わせ， $6 \mathrm{~mol} / \mathrm{L}$ 塩酸で $\mathrm{pH} 2.5$ に調整した。 $10 \mathrm{~mL}$ のメタノールでコンディショニ ングしたInertSep CH カートリッジに, 試験液を $20 \mathrm{~mL} / \mathrm{min}$ の速 度で通水し, 精製水 $20 \mathrm{~mL}$ で洗い込んだ後，15 分間吸引脱水した。 次いで $10 \mathrm{~mL}$ 試験管を受器として $5 \mathrm{~mL}$ のメタノールで溶出した。 溶出液はクリーンアップのため, $10 \mathrm{~mL}$ のメタノールでコンディ ショニングしたInertSep GC/SAX/PSA カートリッジに, $1 \mathrm{~mL} / \mathrm{min}$ 程度の通液速度で負荷し， $12 \mathrm{~mL}$ のメタノールで溶出した。溶出液 は $40{ }^{\circ} \mathrm{C}$ の水浴を備えた窒素吹き付け装置で $0.25 \mathrm{~mL}$ まで濃縮し, 精製水で $0.5 \mathrm{~mL}$ にメスアップし，試験液とした。

なお, 固相抽出後の吸引脱水は, 抽出液中への水の混入を減らす ことを目的として行っており, 脱水時間については $15 \sim 30$ 分程度 で良好であった。また, InertSep GC/SAX/PSA カートリッジから の溶出液量に関しては, 検討の結果, DES を $100 \%$ 回収するため の必要最低限のメタノール量とした。

\section{3. 結果および考察}

\section{1 分析法の定量性とその評価}

3. 1. 1 検量線および装置検出下限, 測定方法の検出下限, 定量 下限

検量線は, $0.0500 \mathrm{ng} / \mathrm{mL}$ から $50.0 \mathrm{ng} / \mathrm{mL}$ の濃度範囲において 相関係数 0.9997 で十分な直線性を示した。また,「化学物質環境実 態調査実施の手引き」16)に記載される方法に従い，検量線の最低濃 度を繰り返し測定して装置検出下限（IDL）を求め, 定量下限值付 近の濃度を持つ試料を前処理から測定まで繰り返し行うことで, 測 定方法の検出下限（MDL）及び定量下限（MQL）を求めた。それ らを Table. 1，2 に示す。

\section{1.2 添加回収}

精製水, 河川水（庄内川）, 海水（名古屋港）に, それぞれ定量 下限（MQL）の 20 倍にあたる標準物質を添加した回収実験の結果 を Table 3 に示す。精製水については $68.4 \%$ の回収率が得られた が, 河川水, 海水に関しては共に $40 \%$ 程度の回収率であった。こ れは 4000 倍の試料濃縮と, 装置への $100 \mu \mathrm{L}$ 注入によるイオン化抑 制に起因すると考えられるが，相対標準偏差が小さいことから，こ のままでも定量的評価は可能と考えられる。また, Table 3 に示し た通り，DES- $d 8$ により補正を行うことで定量值の確かさを確認す ることも可能であると判断される。なお，イオン化抑制の評価に関 
する考察は，3.2.4で述べる。

\section{1.3 試料水中における DES の保存性}

河川水，海水掞よび標準試料の DES の保存性を Table 4 に示す。 試料水ではアスコルビン酸を添加した場合と無添加の場合および, 試料の粗抽出液中の保存性を標準溶液と比較した。

環境水試料中の DES は，アスコルビン酸の有無に関わらず，1 週間の保存が可能であり, 粗抽出液に関しては 2 週間の保存が可能 であった。また, 標準溶液に関しては $0.2 \mathrm{ng} / \mathrm{mL}$ という比較的低 濃度であっても1か月は保存できた。

\section{2 分析法に関する要素技術とその評価}

\section{2. 1 カラム分離}

DES は cis 体 trans 体の異性体を持ち, 通常の $\mathrm{C}_{18}$ カラムでは 2 本のピークに分離された（Fig. 1)。後出のピークは小さく，試料中 濃度が低いとピークが認識されなくなり，定量の感度と精度が低下 するため, 本研究では異性体を分離せず，ピークが1本で分析され

Table 1 IDL value of DES

\begin{tabular}{|l|l|c|}
\hline compound & & DES \\
\hline volume of sample & $(\mathrm{L})$ & 2 \\
\hline volume of prepared sample & $(\mathrm{mL})$ & 0.5 \\
\hline concentration of prepared sample & $(\mathrm{ng} / \mathrm{mL})$ & 0.05 \\
\hline Injection volume for LC/MS & $(\mu \mathrm{L})$ & 100 \\
\hline IDL & $(\mathrm{ng} / \mathrm{mL})$ & 0.0065 \\
\hline limit of detection calculated with IDL & $(\mathrm{ng} / \mathrm{L})$ & 0.0016 \\
\hline standard deviation & $(\mathrm{ng} / \mathrm{L})$ & 0.0017 \\
\hline
\end{tabular}

る Shield RP18 カラムを使用した。

\section{2. 2 固相抽出剤の違いによる回収率の評価}

河川水 $1 \mathrm{~L}$ にDES を $50 \mathrm{ng}$ 添加した試料液を, 2.3 に示す方法 により，以下 7 種類の固相を用いて抽出した。(1) Oasis HLB-Plus (Waters 社製), (2) Sep-Pak-Plus PS-2（Waters 社製), (3) AqusisPLS-3 -Jr 230 mg（GL Sciences 社製），(4) Autoprep EDS-1 250 mg (昭和電工社製)，(5) InertSep CH $500 \mathrm{mg}$ (GL Sciences 社製)， (6) InertSep mini RP-1 $230 \mathrm{mg}$ (GL Sciences 社製), (7) Empore disk SDB-RPS $47 \mathrm{~mm}$ (3 M 社製)。上記固相のうち, (1)〜 (5)について は, 捕集後, メタノール $5 \mathrm{~mL}$ で溶出して, その $20 \mu \mathrm{L}$ をLC/MS へ注入した。結果の概要を Fig. 2 に示す。回収率を算出したところ $62.1 \%$ \% $3.2 \%$ で，大差はなかった。DESは $\log$ Kow が 5.07 程 度と大きいため, (1)から (5)の疎水性固相の構造にほとんど依存せず に捕集, 抽出されたと考えられる。また, 上記(1)～(7)の溶出液に対 して，3.2.3に記述するクリーンアップ操作を行ったところ $10 \%$ 程度の回収率の向上が見られた。

Table 2 MDL and MQL values of DES

\begin{tabular}{|l|l|c|}
\hline compound & & DES \\
\hline volume of sample & $(\mathrm{L})$ & 2 \\
\hline volume of prepared sample & $(\mathrm{mL})$ & 0.5 \\
\hline concentration of prepared sample & $(\mathrm{ng} / \mathrm{mL})$ & 0.05 \\
\hline Injection volume for LC/MS & $(\mu \mathrm{L})$ & 100 \\
\hline MDL & $(\mathrm{ng} / \mathrm{L})$ & 0.005 \\
\hline standard deviation & $(\mathrm{ng} / \mathrm{L})$ & 0.0013 \\
\hline MQL & $(\mathrm{ng} / \mathrm{L})$ & 0.013 \\
\hline
\end{tabular}

Table 3 Recoveries (\%) of DES in purified water, river water and sea water

\begin{tabular}{|l|c|c|c|}
\hline types of water samples & purified water & river water & sea water \\
\hline volume of sample (L) & 2 & 2 & 2 \\
\hline amount of spiked DES (ng) & 0.5 & 0.5 & 0.5 \\
\hline number of experiments & 2 & 5 & 5 \\
\hline recovery (\%) & 67 & 45 & 45 \\
\hline Surrogate recovery (\%) & 68 & 43 & 42 \\
\hline recovery (corrected with surrogate) (\%) & 98 & 104 & 106 \\
\hline R.S.D.(\%) & & 4.0 & 2.9 \\
\hline
\end{tabular}

Table 4 DES recoveries from preserved samples

\begin{tabular}{|c|c|c|c|c|c|}
\hline & \multirow[t]{2}{*}{ sample } & \multirow{2}{*}{\begin{tabular}{|c|} 
concentration of \\
prepared sample
\end{tabular}} & \multicolumn{3}{|c|}{ recovery $(\%)$} \\
\hline & & & 7 days & 14 days & 1 month \\
\hline & sample added with ascorbic acid & 0.2 & 88 & & \\
\hline \multirow[t]{3}{*}{ river water } & sample in plain & 0.2 & 90 & & \\
\hline & raw extract in methanol & 0.4 & & 95 & \\
\hline & sample added with ascorbic acid & 0.2 & 85 & & \\
\hline \multirow[t]{2}{*}{ sea water } & sample in plain & 0.2 & 85 & & \\
\hline & raw extract in methanol & 0.4 & & 98 & \\
\hline \multirow{2}{*}{ standard solution } & 10 times of MDL in concentration & 0.2 & & & 100 \\
\hline & highest concentration in the working curve & 50 & & & 96 \\
\hline
\end{tabular}


いずれの固相も回収率に大差はないが, クリーンアップ後の回収 率が最も高かった(5) InertSep CH $500 \mathrm{mg}$ を選択した。尚, 2 L の試 料を通水する際に破過することが懸念されたため, 固相を 2 連にし て同様に操作を行ったが，2段目の固相への破過は認められなかっ た。

\section{2. 3 クリーンアップ方法の検討}

本分析では，前処理における濃縮率が高いため，試料マトリック スによるイオン化抑制が無視できない。都市の河川水から抽出さ れる主な夾雑成分としては陰イオン (LAS), 非イオン界面活性剤 (NPnEO) 及びその分解物 $(\mathrm{NPnEC})$, クロロフィル等が考えられ, これらの物質のうち, LAS, NPnECの多くは, DES の保持時間（11 分）付近に検出された。環境水中濃度としては LAS が約 $10 \mathrm{ng} / \mathrm{mL}$ と $\mathrm{NPnEC}$ が約 $1 \mathrm{ng} / \mathrm{mL}$ と低濃度であるが, 試料液の濃縮率を高
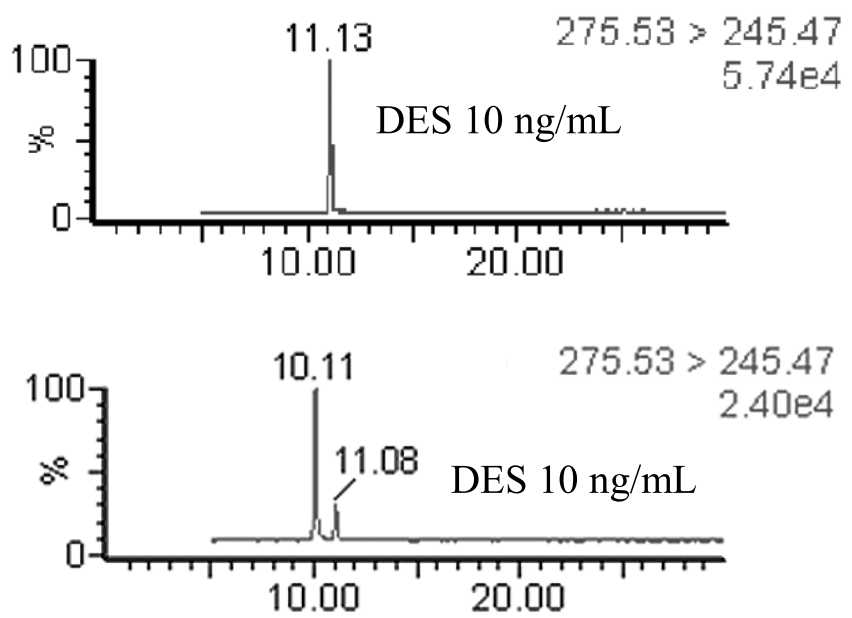

Fig. 1 Difference in separation of DES isomers between two types of HPLC columns

upper: XBridge TM Shield RP18, down: a conventional C18 column

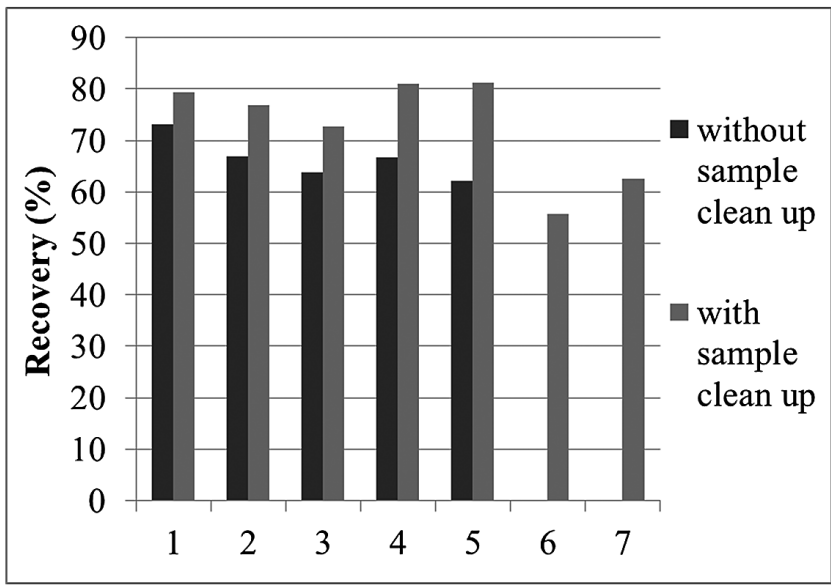

Fig. 2 Recoveries of DES from river water by using seven SPE cartridges

1. Oasis HLB-Plus (Waters), 2. Sep-Pak-Plus PS-2 (Waters),

3. Aqusis-PLS-3-Jr $230 \mathrm{mg}$ (GL Sciences), 4 . Autoprep EDS-1 $250 \mathrm{mg}$ (Showa-denko), 5. InertSep CH $500 \mathrm{mg}$ (GL Sciences), 6. InertSep mini RP-1 $230 \mathrm{mg}$ (GL Sciences), 7 . Empore disk SDB-RPS $47 \mathrm{~mm}(3 \mathrm{M})$
くするため, 夾雑成分もかなり高濃度になることが考えられ, クリー ンアップ方法の検討を行った。

(1) クリーンアップの候補固相に関する DES 抽出率の検討

試料のクリーンアップのために, 活性炭カートリッジを用いる方 法を検討した。(1) Inertsep GC (GL Sciences 社製), (2) ENVI-Carb (SUPELCO 社製), (3) Autoprep AC (昭和電工社製), (4) SeP-PAK $\mathrm{AC} 2$ (waters 社製) の 4 種類の固相について検討を行った。DES の回収率を Fig. 3 に示す。

精製水 $10 \mathrm{~mL}$ にDES $20 \mathrm{ng}$ を添加したものを試験液とし, 上記 の活性炭カートリッジに通液した。カートリッジからの溶出は第一 分画 (F1) メタノール $12 \mathrm{~mL}$, 第二分画 $(\mathrm{F} 2)$ メタノール $12 \mathrm{~mL}$ で行った。結果，(1)抢よび(2)は，F1のみで $98.6 \%, 98.8 \% の$ DES の回収率が得られた一方で, (3)およ゙(4)からはF1，F2 とも にDES は全く回収されなかった。(1), (2)はいずれも (3), (4)の活性 炭に比べ表面積の小さいグラファイトカーボンであることによるた め, DES との相互作用が比較的小さく，良好な回収率が得られた と考えられる。

(2) 活性炭系固相による主要夾雑成分の除去効率の検討

次に，(1）の検討試料と同様の試料に, 夾雑成分として, 陰イオ ン界面活性剂 (LAS) $200 \mathrm{ng}$, 非イオン界面活性剂の分解物 (NPnEC) $20 \mathrm{ng}$ を添加し，(1)〜 (4)の活性炭カートリッジに通液した。カート リッジからの溶出は第一分画 (F1) メタノール $12 \mathrm{~mL}$, 第二分画 (F2) メタノール $12 \mathrm{~mL}$ で行った。

（1）の検討結果より，(1)，(2)の固相においてはDESが $100 \%$ 近 く回収されているはずであるにも関わらず，いずれの場合におい ても回收率は低く, 最も高い(1)でも，22\%程度の回収率であった。 一方で, 夾雑成分として添加したLASやNPECは, その多くが試 験液中に回収されていたこと, 活性炭系固相を通す前の未処理試料 を測定しても回収率が $20 \%$ 程度であること，の 2 点を合わせて考 察すると，DESが回収されていないのではなく，イオン化抑制に より, 見かけ上, 回収率が悪いことが示唆された。そこで, 環境試 料中の DES のクリーンアップを行う際には, 活性炭カートリッジ のみでは不十分であり, 陰イオン交換作用や極性相互作用を持つ固 相を合わせて使用することとした。

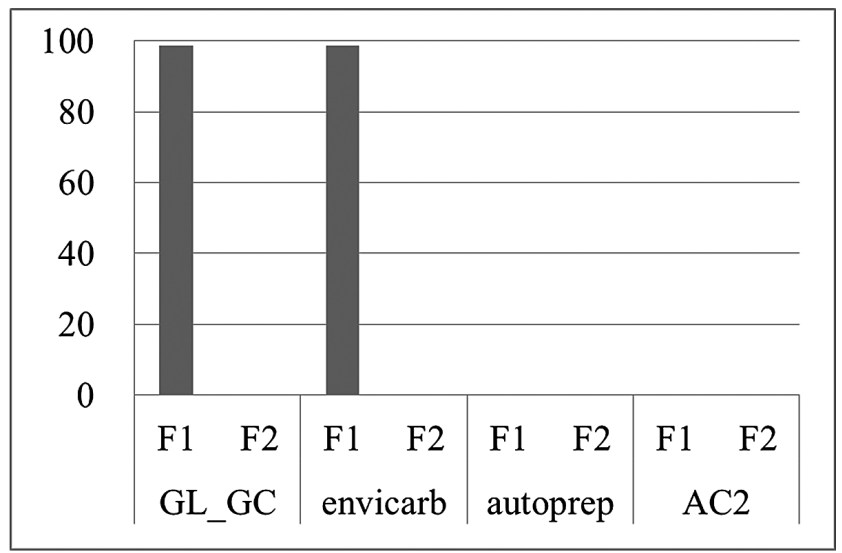

Fig. 3 Recoveries (\%) of DES from purified water by using 4 kinds of activated carbon cartridges

$\mathrm{F} 1$ : the first fraction with $12 \mathrm{~mL}$ of Methanol,

$\mathrm{F} 2$ : the second fraction with another $12 \mathrm{~mL}$ of Methanol 
上記 4 種類の固相の中で回収率のよかった(1) Inertsep GC を中心 に, 極性相互作用と弱陰イオン交換作用を持つ PSA, 強陰イオン交 換作用を持つ SAX を組み合わせた GC/PSA および, GC/SAX/PSA を用いて検討を行った。

上記検討と同様に, 精製水 $10 \mathrm{~mL}$ にDES $50 \mathrm{ng}$ と, さらに夾雑 成分として, 陰イオン界面活性剂（LAS） $200 \mathrm{ng}$, 非イオン界面活 性剂の分解物 (NPEC) $20 \mathrm{ng}$ を添加したものを試験液として, 固 相カートリッジへ通液した。固相カートリッジからの溶出は第一分 画（F1）メタノール $12 \mathrm{~mL}$ ，第二分画（F2） $2 \%$ ギ酸/メタノール $12 \mathrm{~mL}$ で行った。DES, LAS, NPECの回収率をそれぞれ Fig. 4，5，

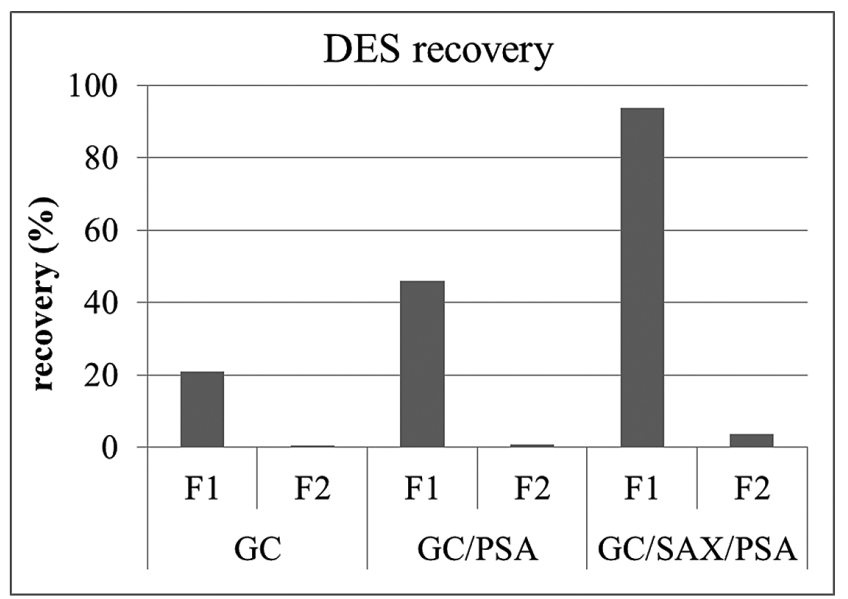

Fig. 4 Recoveries (\%) of DES from purified water by using three SPE cartridges

$\mathrm{F} 1$ : the first fraction with $12 \mathrm{~mL}$ of Methanol $12 \mathrm{~mL}$, $\mathrm{F} 2$ : the second fraction with another $12 \mathrm{~mL}$ of Methanol. GC: Inertsep GC, GC/PSA: InertSep GC/PSA, GC/SAX/PSA: InertSep GC/SAX/PSA

(GC: Graphite Carbon, PSA: Primary-Secondary Amine, SAX Strong Anion eXchange)

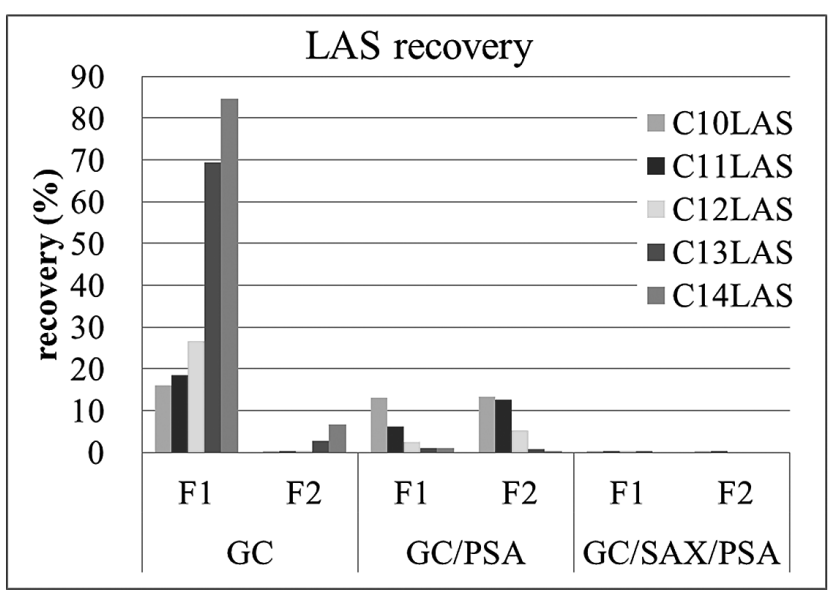

Fig. 5 Recoveries (\%) of LAS from purified water using activated carbon SPE cartridges

$\mathrm{F} 1$ : the first fraction with $12 \mathrm{~mL}$ of Methanol (DES is eluted in this fraction)

$\mathrm{F} 2$ : the second fraction with $12 \mathrm{~mL}$ of $2 \% \mathrm{HCOOH} /$ Methanol.

GC, GC/PSA and GC/SAX/PSA are the same abbreviations as those in Fig. 4.
6 に示す。

DES がF1に溶出することを考慮すると，イオン化抑制を抑え るためには，F1にLAS およびNPECが溶出しないことが望まし い。Fig. 5，6より，GCを用いた場合，LAS や NPECの多くが F1 に溶出し，クリーンアップが十分にできていないことが示された。 GC/PSA を用いた場合, GC と比較するとクリーンアップ効果が期 待できるが, 10 〜 $20 \%$ 程度が F1に溶出してくる結果となった。 一方で GC/SAX/PSA を用いると LAS, NPEC ともにF1にはほと んど溶出してこなかった。これは SAX, PSAの両方の効果により， LAS, NPEC が十分に保持されたためだと考えられる。

Fig. 4より, 各クリーンアップカートリッジを用いた際の回収率 を比較すると, GC, GC/PSA, GC/SAX/PSAの順で回収率が高くなっ た。これは, Fig. 5，6の結果からもわかるように，試料液中の夾 雑成分が除去され，イオン化抑制の影響を抑えることができたため であると考えられる。

実際，環境試料にこの固相を適用した結果，LAS，NPnEC は $90 \%$ 以上除去され, クロロフィル等の色素も除去された。以上の 検討結果より，試料液のクリーンアップには GC/SAX/PSA 固相を 用いることとした。

\section{2. 4 試料濃縮率及び LC/MS への注入量の違いによる回収率 への影響}

精製水及び河川水, 海水 $2 \mathrm{~L}$ に DES を $50 \mathrm{ng}$ 添加して, InertSep $\mathrm{CH}$ カートリッジで抽出し, InertSep GC/SAX/PSA カートリッジ でクリーンアップした試料を，濃縮倍率ごとに回収率を比較した。 濃縮倍率が 200, 1000, 2000 倍と変わっても, クリーンアップ操作 をしていれば，回収率に大差はなかった。

ただし，本法ではDESの微量分析を行っており，目的の感度を 得るためには, LC/MSへの注入量を, 通常の 20 倍程度にする必 要がある。 $5 \mu \mathrm{L}$ 程度の注入量であれば，特に注意の必要はないが， 今回は $100 \mu \mathrm{L}$ の大容量を注入するため, 最終溶液の溶媒組成も併 せて測定結果への影響を検討した。結果, LC/MSへの注入量が $50 \mu \mathrm{L}$ 以上の場合, 最終溶液の溶媒組成を, 移動相の初期状態の組 成に近つけないとピーク形状が悪くなった。一方で、最終溶液に水

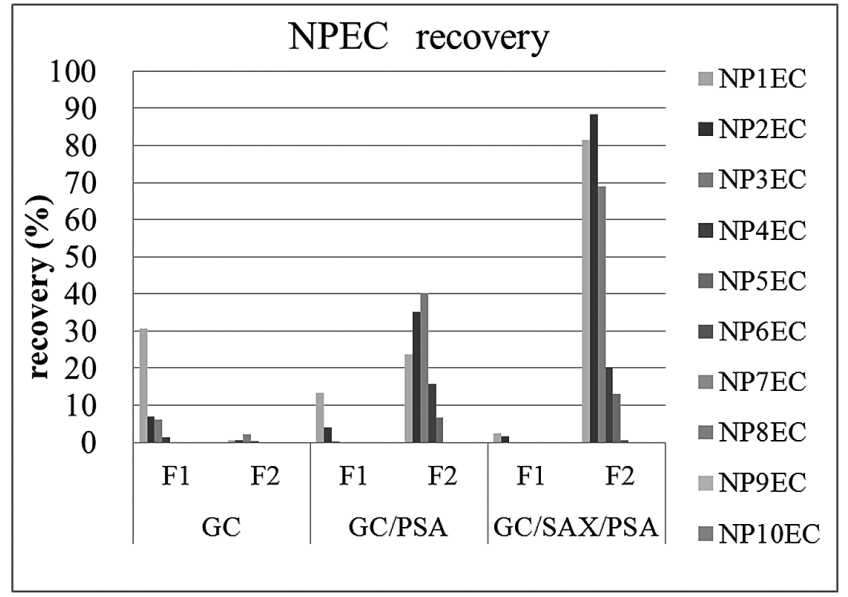

Fig. 6 Recoveries (\%) of NPEC in purified water collected in ac tivated carbon SPE cartridges

$\mathrm{F} 1$ : the first fraction with $12 \mathrm{~mL}$ of Methanol (DES is eluted in this fraction)

$\mathrm{F} 2$ : the second fraction with $12 \mathrm{~mL}$ of $2 \% \mathrm{HCOOH} / \mathrm{Methanol}$ GC, GC/PSA and GC/SAX/PSA are the same abbreviations as those in Fig. 4 
を加えることによるDES の不溶解物質への吸着や溶解度の低下が 影響し, 見かけ上の回収率は低下した。結果、ピーク形状を良好に 保つ限界の溶媒組成比メタノール：水＝1：1を最終溶液として選 択した。

2.3 に示す方法に従って処理（4000 倍濃縮）した精製水および 海水試料を $5 \sim 100 \mu \mathrm{L}$ 注入した場合の回収率を Fig. 7 に示す。注 入量が増加するとサロゲートの絶対回収率が低下した。しかし, Table 2 の添加回収試験結果に示す通り, DES- $d_{8}$ による回収率補正 を行うことにより，98％以上の回収率が得られた。

\section{3 環境試料の測定結果}

名古屋市内河川水および名古屋港海水を本法により分析した結果 を，Fig. 8, Fig. 9 に示す。Fig. 8 は名古屋市内北部を流れる庄内川 中流域で採水した河川水を分析した結果で, DESは $0.005 \mathrm{ng} / \mathrm{L}$ 以 下で検出されなかった。Fig. 9 は名古屋市内中部を流れる堀川の河 口部で採水した海水を測定した結果で，DES は同じく $0.0050 \mathrm{ng} / \mathrm{L}$ 以下で検出されなかった。Fig. 9 で, DES の保持時間付近に未知物 質のピークが検出されたが，同じ試料を用いて添加回収試験を行っ たところ,この未知物質は DES とは分離され, 定量に問題はなかっ た。

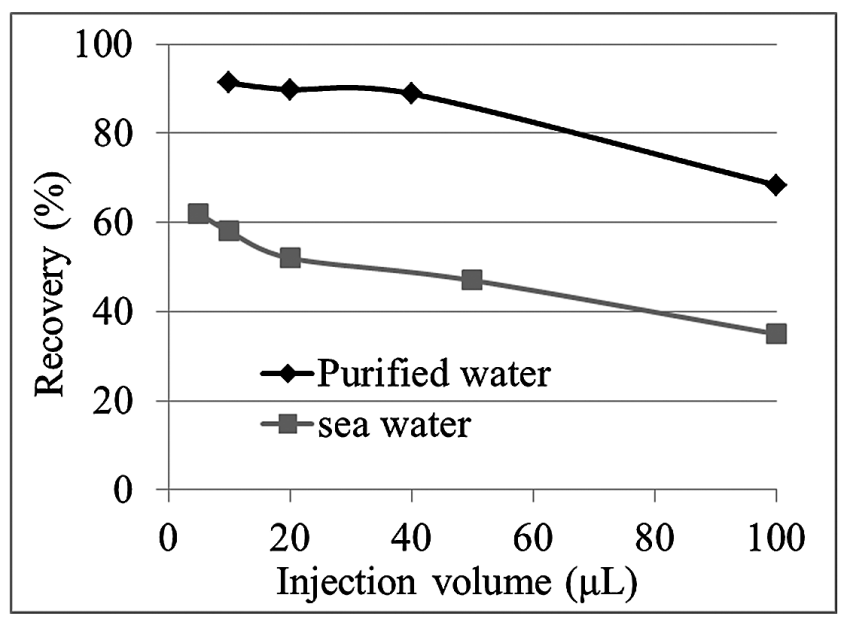

Fig. 7 Effect of injection volume on overall recoveries (\%) of DES_ $d 8$ in purified water and sea water samples
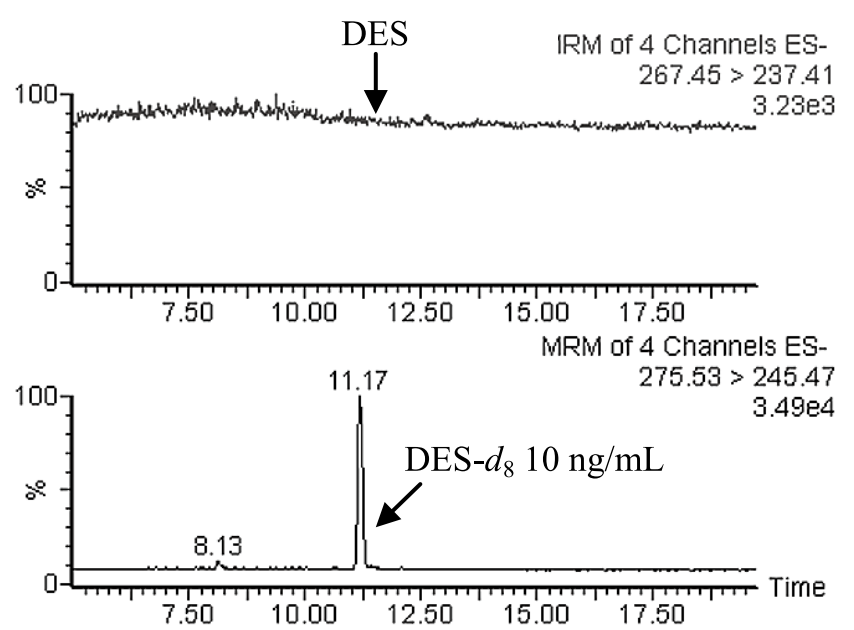

Fig. 8 An SRM chromatogram of DES in river water
いずれの地点からも DES は検出されなかったが, これは日本国 内に括いて, DESの使用が非常に限られており, 前立腺癌の治療 薬「ホンバン錠」として一部で使用されているのみであるためと考 えられる。このことを考慮すると, 病院排水など, 限られた水質污 染の確認の課題は残るが, 現在はこの薬剤も製造中止になっている ため，環境への影響は低いと考えられる。

\section{4. まとめ}

本報告ではDES の極微量分析を行うため, 試料のクリーンアッ プ方法, 大量試料導入方法を検討し, LC/MS/MSによる分析方法 を開発した。本法によって、環境水中の DES を界面活性剂などの 夾雑成分による影響を抑え, DESの回収率 98 \% 以上で安定して分 析できた。また，複数箇所の水質試料を用いて MDLを計算したと

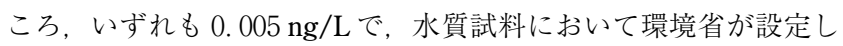
たDESの検出下限值 $0.01 \mathrm{ng} / \mathrm{L}$ を満足した。

本研究の一部は,「化学物質分析法開発事業」(平成 21 年度環境 省委託）によった。

\section{要 約}

環境省の要求する検出下限值 $(0.01 \mathrm{ng} / \mathrm{L})$ を満足する環境水中 のDESの高感度分析方法を開発し, 環境調査を行った。環境水 を高濃縮し大量試料導入するため, 機器分析の際に夾雑成分の影 響を抑制する方法を検討し, 固相抽出後, GC/SAX/PSA を用いて クリーンアップを行う方法を開発した。本分析法の検出下限值は $0.005 \mathrm{ng} / \mathrm{L}$, 定量下限值は $0.013 \mathrm{ng} / \mathrm{L} て ゙$, 添加回収率は河川水で $104 \%$, 海水で $106 \%$ であった。名古屋市内に扔いて環境調査を行っ た結果，河川水，海水ともに不検出であった。

\section{文 献}

1）武田玲子, 吉田由布子：「ピルの危険な話」東京書籍, （2000）

2) Herbst, A.L., Ulfelder, H. and Poskanzer, D.C.: Adenocarcinoma of the vagina. Association of maternal stilbestrol therapy with tumor appearance in young women. $N$ Engl J Med., 284, 878-881 (1971).

3) Henderson, B.E., Benton, B., Cosgrove, M., Baptista, J., Townsend, D. and Hart, W., Mack, TM.: Urogenital tract abnormalities in sons of women treated with diethylstilbestrol. Pediat-

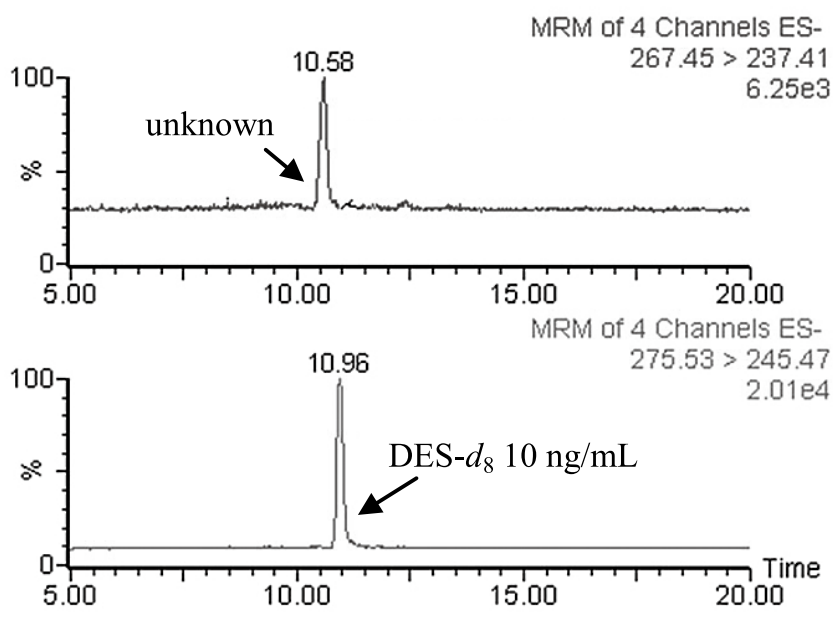

Fig. 9 An SRM chromatogram of DES in sea water 
rics, 58, 505-507 (1976)

4) Mittendorf, R.: Teratogen update carcinogenesis and teratogenesis associated with exposure to diethylstilbestrol (DES) in utero. Teratology, 51, 435-445 (1995).

5) Giusti, R.M., Iwamoto, K. and Hatch E.E.: Diethylstilbestrol revisited: a review of the long-term health effects. Ann Intern Med., 122, 78-88 (1995).

6) Herbst, A.L.: Behavior of estrogen-associated female genital tract cancer and its relation to neoplasia following intrauterine exposure to diethylstilbestrol (DES). Gynecol Oncol, 76, 147-156 (2000).

7) Vom Saal, F. S., Barry G.T., Monica, M.M., Paola, P., Kristina, A.T., Susan, C.N., Minati, D.D., V.K. Ganjam, Stefano, P. and Wade, V.W.: Prostate enlargement in mice due to fetal exposure to low doses of estradiol or diethylstilbestrol and opposite effects at high doses. Proc. Natl. Acad. Sci. USA, 94, 2056-2061 (1997).

8) Zhong X., Xu Y., Liang Y., Liao T. and Wang J.: The Chinese rare minnow (Gobiocypris rarus) as an in vivo model for endocrine disruption in freshwater teleosts : a full life-cycle test with diethylstilbestrol., Aquatic Toxicology., 71(1), 85-95 (2005)

9) Yamamoto, A., Kakutani, N., Yamamoto, K., Kamiura, T. and Miyakoda, H.: Steroid hormone profiles of urban and tidal rivers using LC/MS/MS equipped with electrospray ionization and atmospheric pressure photoionization sources., Environ. Sci. Technol., 40, 4132-4137 (2006).

10) Jeannot, R., Hassan, S., Emmanuel, S., Thierry, D. and Katja, D.:
Determination of endcrine-disrupting compounds in environmental samples using gas and liquid chromatography with mass spectrometry., J. Chromatogr. A, 974, 143-159 (2002).

11) Benijts, T., Dams, R., Gunther, W., Lambert, W. and Leenheer, A.D.: Analysis of estrogenic contaminants in river water using liquid chromatography coupled tp ion trap based mass spectrometry, Rapid Commun. Mass Spectrom., 16, 1358-1364 (2002).

12) Lopez, de Alda, M.J. and Barcelo, D.: Use of solid-phase extraction in various of its modalities for sample preparation in the determination of estrogens and progestogens in sediment and water, J. Chromatogr. A, 938, 145-153 (2001).

13) Pedrouzo, M., Borrull F., Pocurull E. and Maria M.R.: Estrogens and their conjugates: Determination in water samples by solidphase extraction and liquid chromatography-tandem mass spectrometry, Talanta, 78, 1327-1331 (2009).

14) Chen, H.C., Kuo H.W. and Ding W.H.: Determination of estrogenic compounds in wastewater using liquid chromatographytandem mass spectrometry with electrospray and atmospheric pressure photoionization following desalting extraction, Chemosphere, 74, 508-514 (2009).

15) Lei, B., Huang, S., Zhou, Y., Wang, D. and Wang, Z.: Level of six estrogens in water and sediment from three river in Tianjin area, China, Chemosphere, 76, 36-42 (2009).

16）環境省総合環境政策局環境保健部環境安全課：「化学物質環境 実態調査実施の手引き」（2009） 